\title{
Introductory address for the 2014 John Howland award recipient, Rebecca H. Buckley
}

\author{
E. Richard Stiehm ${ }^{1}$
}

This introduction was presented at the 2014 Annual Meeting of the Pediatric Academic Societies, Vancouver, Canada.

am pleased to introduce Rebecca Hatcher Buckley, Professor of Pediatrics at Duke University, as the recipient of the 2014 Howland Award for her studies in primary immunodeficiency, notably the early diagnosis and treatment of severe combined immunodeficiency.

Dr Buckley is the eighth female recipient of the Howland Award (Figure 1). Although the American Pediatric Society (APS) was founded in 1888, it was not until 1928 that the first woman, Ethel Duncan, was elected to membership. Ethel Duncan was also the first woman Howland awardee (in 1958). But in the last decade, three women have received the award: Mary Ellen Avery in 2005, Elizabeth McAnerney in 2013, and Rebecca Buckley in 2014. These three women, and the 1996 awardee, Mildred Stahlman, have served as presidents of the American Pediatric Society.

Rebecca Buckley was born in the tiny village of Hamlet in the Sandhill district of North Carolina in the depths of the Depression. Her family, while not wealthy, were spared the ravages of that era as her father was one of three GPs in town (Figure 2). Little Becky's first introduction to medicine was listening to her father receiving late-night patient calls as the telephone was just outside her bedroom. Then and there did she decide to become a doctor.

Several years ago, I presented an award from the Immune Deficiency Foundation to Dr Buckley. For background information, I called her mother, then age 91, still living in Hamlet, to ask about Rebecca as a girl growing up. These were her words: "That girl was always busy: dancing recitals, music lessons, church choir, Nancy Drew mysteries, debate team, yearbook editing - why, I never had any trouble with that girl! She was the kind of girl that other mothers said to their daughters, "Why can't you be more like Becky Hatcher?"

Becky sailed uneventfully through her school years (Figures 3-5) as a 5-year-old dancer, a Washington, DC, tourist during her early teens, and a basketball player during high school. In high school, she developed a deep and abiding passion for basketball. This basketball obsession has continued to the present: she is the number one fan of Duke's winning basketball team.
Rebecca was the only person in her Hamlet High School class of 1955 who went to college-to Duke University, 100 miles away. Her college graduation picture (Figure 6) shows her with her beloved pearls, which she still wears to this day. She then attended medical school at the University of North Carolina, one of three women in her class of 60 .

She returned to Duke for a pediatric residency and fellowship with allergist Susan Dees and immunologist Richard Metzgar. She joined the Duke faculty in 1968 and has been at Duke ever since.

Dr Buckley's main interest has been the study of immunodeficiency, now thought to affect one in 12,000 individuals. She and colleagues have characterized five distinct immunodeficiencies. The best known is the hyper-IgE syndrome, also called the Buckley syndrome or Job's syndrome, the latter named after the biblical Job who was "smote with sores from the sole of his foot unto his crown" (Job 2:7).

Dr Buckley is best known for her bone marrow transplants for infants with severe combined immunodeficiency (SCID) who do not have a matched sibling donor. She uses marrow from a parent depleted of mature T cells, given without pretransplant conditioning or posttransplant graft-versus-host medications. Her 171 transplants-the largest US single-center experience-have had remarkable clinical success.

From these studies came two important observations. The first is that marrow transplantation in the first months of life, before the baby is infected, is very successful. Second, that nearly all SCID babies have profound lymphopenia. This characteristic is the basis for newborn screening. A heel-stick bloodspot is subjected to a PCR test for new lymphocytes, which are low or absent in SCID infants. Early diagnosis allows for early treatment and avoidance of live vaccines.

Dr Buckley was a key member of the HHS Advisory Committee on Inherited Disorders that recommended SCID screening for every US newborn. This screening has been initiated in half of the states and several countries worldwide.

She remains active as a clinician and teacher. She has served as a mentor for 100 fellows in allergy and immunology, has been a visiting professor at many universities and hospitals, and has given countless lectures here and abroad. She and her husband, 





1958 Ethel Dunham Yale, US Children's Bureau

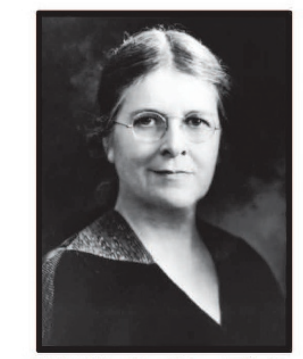

1967 Martha May Eliot Yale, US Children's Bureau

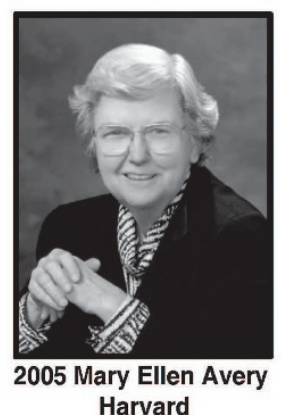

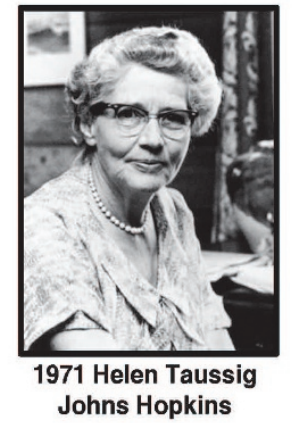





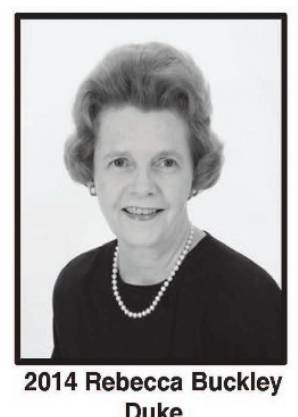

Figure 1. Female recipients of the Howland Award, 1958-2014. Ethel Duncan (1958) was a pioneer in research on causes and management of the premature infant. Martha Elliot (1967) established the relationship between rickets and vitamin D, and later administered the US Children's Bureau. Helen Taussig (1971) developed, with Alfred Blalock, the cardiac operation to correct tetralogy of Fallot. Helen Harrison (1983) studied disorders of calcium and phosphorus metabolism. Mildred Stahlman (1996) developed intensive care units for ventilation of premature infants. Mary Ellen Avery (2006) showed that infants with respiratory distress syndrome lacked surfactant, and that its use could treat these infants. Elizabeth McAnarney (2013) was a pioneer in the field of adolescent medicine.

fellow allergist Edward Buckley, MD, have visited over 40 countries. She has accomplished all of this while raising a family of four talented children and two grandchildren (Figure 7).

Her many honors are too numerous to list. I will mention just a few, as if they were competing for a basketball championship. The fabulous four include (i) president of the American Academy of Allergy, Asthma, and Immunology, (ii) president of the American Board of Allergy and Immunology, (iii) the Lifetime Achievement Award of the Immune Deficiency Foundation, and (iv) the Distinguished Teaching Award from the Duke Medical Alumni Association.

The finalists are (i) president of the American Pediatric Society and (ii) election to the Institute of Medicine of the National Academy of Sciences.

The winner is her election to the National Academy of Sciences in 2011. This must now be shared with the Howland Award, the highest honor in American pediatrics.

Dr Buckley's nomination was supported by colleagues throughout the United States. Excerpts from their supporting letters follow.
Kurt Hirschorn, Chair Emeritus of Pediatrics of Mt. Sinai and a former Howland awardee, writes, "I have always been greatly impressed by her service to child health, her teaching ability, and her devotion to the American Pediatric Society, including holding its presidency in 1996."

Richard Johnston of the University of Colorado and a former Howland awardee writes, "The consistently high quality of what Dr Buckley has done and her unselfish service to immunology and pediatrics have led to an exceptionally large number of leadership positions."

Jennifer Puck of UC San Francisco writes, “One of Dr Buckley's great strengths is seeing the big picture, i.e., that early treatment of SCID infants before the onset of infections is associated with much better outcomes and can be identified by their low absolute lymphocyte counts."

R. Rodney Howell of the University of Miami writes, "As a fellow house officer, Becky was thorough, inquisitive, and creative. Her experience with identifying and treating SCID infants has saved the lives of many infants and will save the lives of future infants identified by newborn screening." 


\section{Introductory address: Howland Award $\quad$ Special Article}

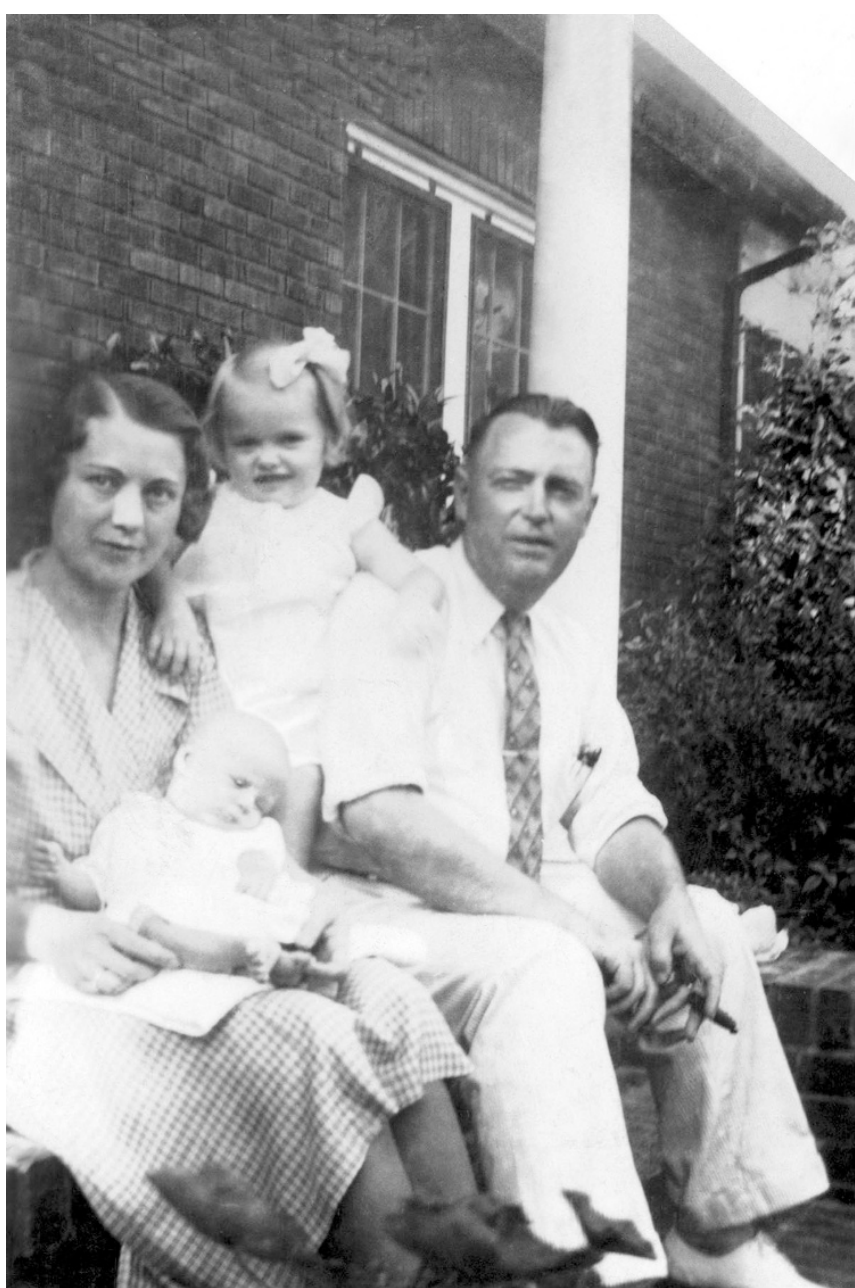

Figure 2. Rebecca at age 2 with her mother, Nora Hatcher, and father, Dr Martin Hatcher, and baby brother, Martin Jr. Copyright by C. Edward Buckley, MD. Reprinted with permission.

Michael Frank, Chair Emeritus of Pediatrics of Duke, writes, "Dr Buckley had the foresight to freeze cells from all of her SCID patients and families to understand the defects present, even though they were cured by bone marrow transplantation."

William Shearer of Baylor University writes, "Dr Buckley is a role model for young faculty with her personal involvement in both laboratory research and translation of that work to clinical practice."

John Sleasman, Chief of Allergy/Immunology at Duke, writes, "Her division has been an incubator for some of our greatest pediatric allergists and immunologists. She has always been there to assist and advise those of us with lesser skills who also treat these complex patients on a day-to-day basis."

Hans Ochs of the University of Washington writes, "Her ability to interest students, fellows, and others in primary immunodeficiency is legendary, as attested by the numerous invitations to lecture at national and international meetings."

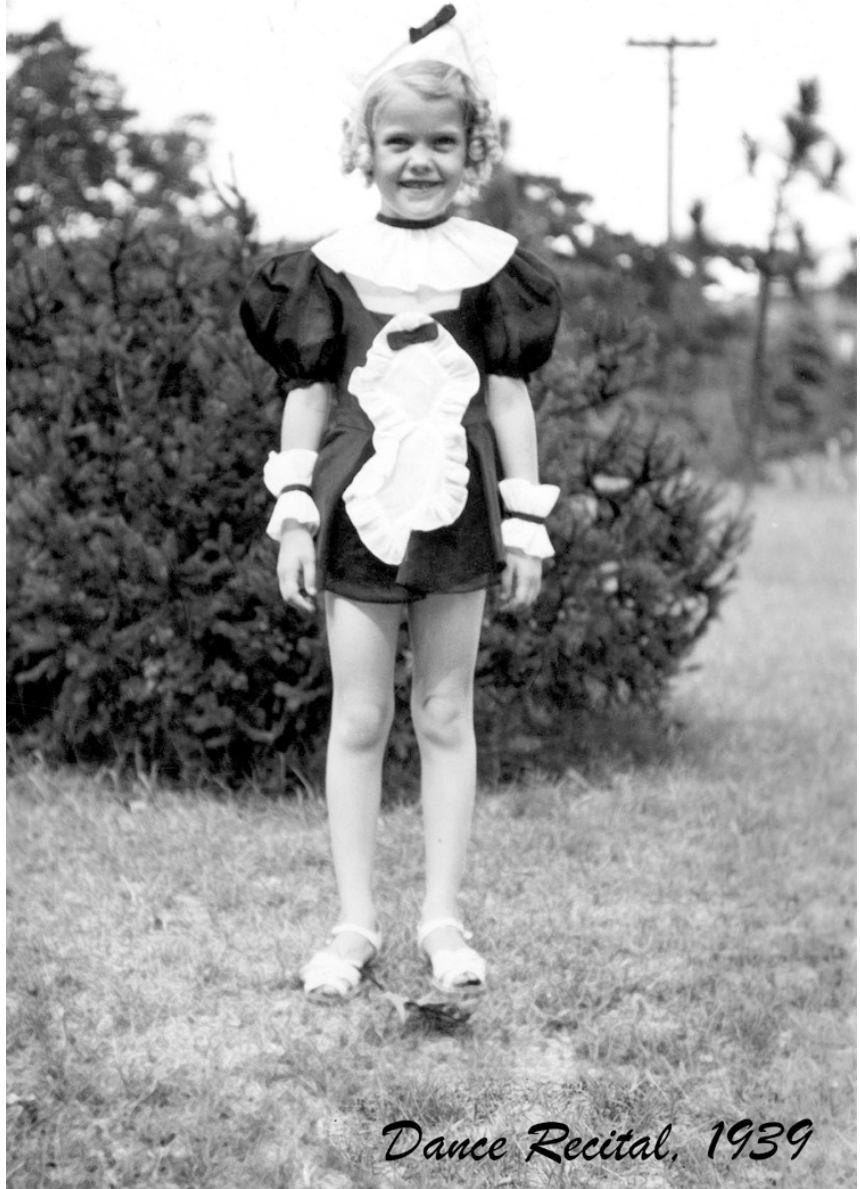

Figure 3. Rebecca, age 5 , is preparing for a dance recital. Copyright by $C$. Edward Buckley, MD. Reprinted with permission.

Hugh Sampson of Mt. Sinai, a former trainee, writes, "I had the privilege of working with Dr Buckley on the early transplants and was struck by her attention to detail and the unrelenting care she provided to these early patients and their families. I believe she is one of the outstanding pediatric investigators of our times."

M. Louise Markert of Duke, a former trainee, writes, "I must emphasize the dedication Dr Buckely has to her patients. She is happy to provide advice about patient problems even when she is on vacation, at the beach, or late at night. She came to clinic with a cast on her foot, not wanting to let her patients down."

Laurence Boxer of the University of Michigan writes, "I had the opportunity to acquire the management of one of her former patients who moved from North Carolina to Ann Arbor. I was most impressed by the affection that the family had for Dr Buckley and her staff. Without question, Dr Buckley represents the best of academic pediatrics in terms of her research, patient care, and leadership."

Mike Krzyzewski ("Coach K”) of the Duke University basketball team also wrote a letter: 


\section{Special Article}

\section{Stiehm}

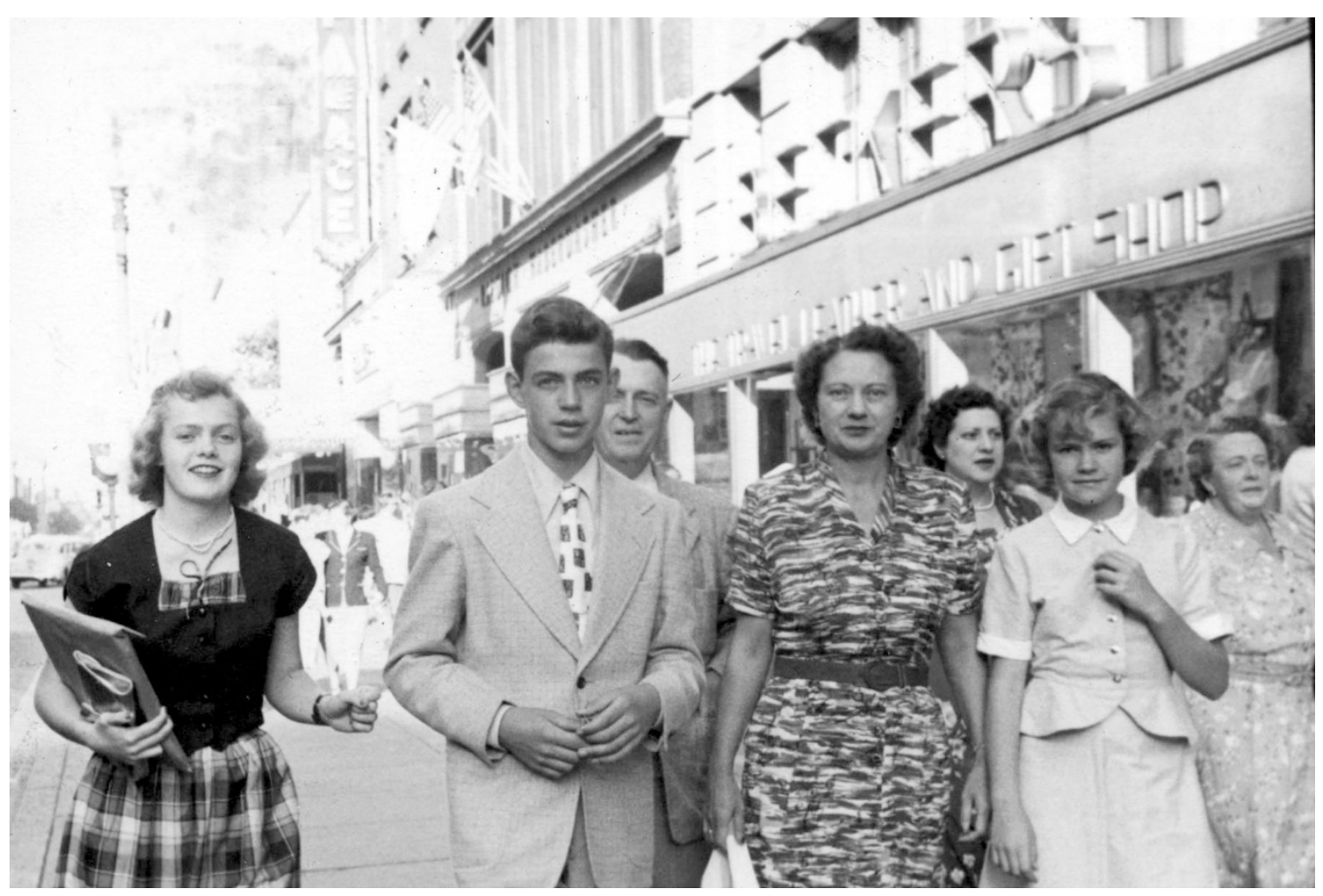

Figure 4. Rebecca, age 13, on vacation in Washington, DC, with her family. Copyright by C. Edward Buckley, MD. Reprinted with permission.

\begin{abstract}
Dear Rebecca,
Congratulations. You have always been on our team and it is my honor to be on your team as you are presented with the Howland award. You have followed us closely over the years. As good as my players have been, you have been better. In fact, you have been extraordinary! I must agree with your mother as you were growing up in Hamlet: "I knew: she was going to make something of herself." We are so proud and happy for you. Best wishes always, Mike
\end{abstract}

At the Howland dinner, held at the Vancouver Fairmont hotel the eve of the award ceremony, three colleagues made brief remarks.

Joseph St Geme III, Chair of Pediatrics at Children's Hospital of Philadelphia and former Chair of Pediatrics at Duke:

"It's an honor and a special privilege to make some comments about Becky Buckley, who is clearly a giant in pediatrics. As we heard in some detail this morning, she has been a worldrenowned clinician and investigator in pediatric immunology for decades and has transformed our understanding of primary pediatric immunodeficiency diseases.

I had the privilege of working closely with Becky for 8 years, from 2005 to 2013, while Chair of Pediatrics at Duke. Based on my interactions with her during this period and my observations over a much longer period of time, I'd like to highlight a few words that epitomize her persona.
The first word is decorated. Alongside Sam Katz, Becky is undeniably the most decorated member of the Department of Pediatrics at Duke in the history of the department. As detailed in Dr Stiehm's introduction, she has received over 60 honors over the course of her career, most notably including election to the Institute of Medicine and election to the National Academy of Sciences. In Becky's case the word "decorated" has an additional connotation and refers to the fact that she always wears a string of beautiful pearls. These pearls have become her trademark and symbolize her grace, her elegance, and her air of royalty.

The second word is respect. I remember my first meeting with Wesley Burks in 2005 to review the faculty in the Division of Allergy and Immunology in his role at the time as chief of the division. We discussed them one by one, beginning with the junior faculty and then moving to the more established faculty. Wesley referred to Laurie, and Joe, and Larry, and Louise. He referred to Mike, meaning Mike Frank, who preceded me as chair of the department and had returned to the division to resume his research interests. And then he referred to Dr Buckley as Dr Buckley. He had first met Becky when he was a fellow and was charting his own career, and he could not bring himself to call her Becky, even 25 years later as her division chief. From his perspective, at some level she was still the chief. The closest he could get was to call her Dr B. reflecting his enormous respect for her. 


\section{Introductory address: Howland Award $\quad$ Special Article}

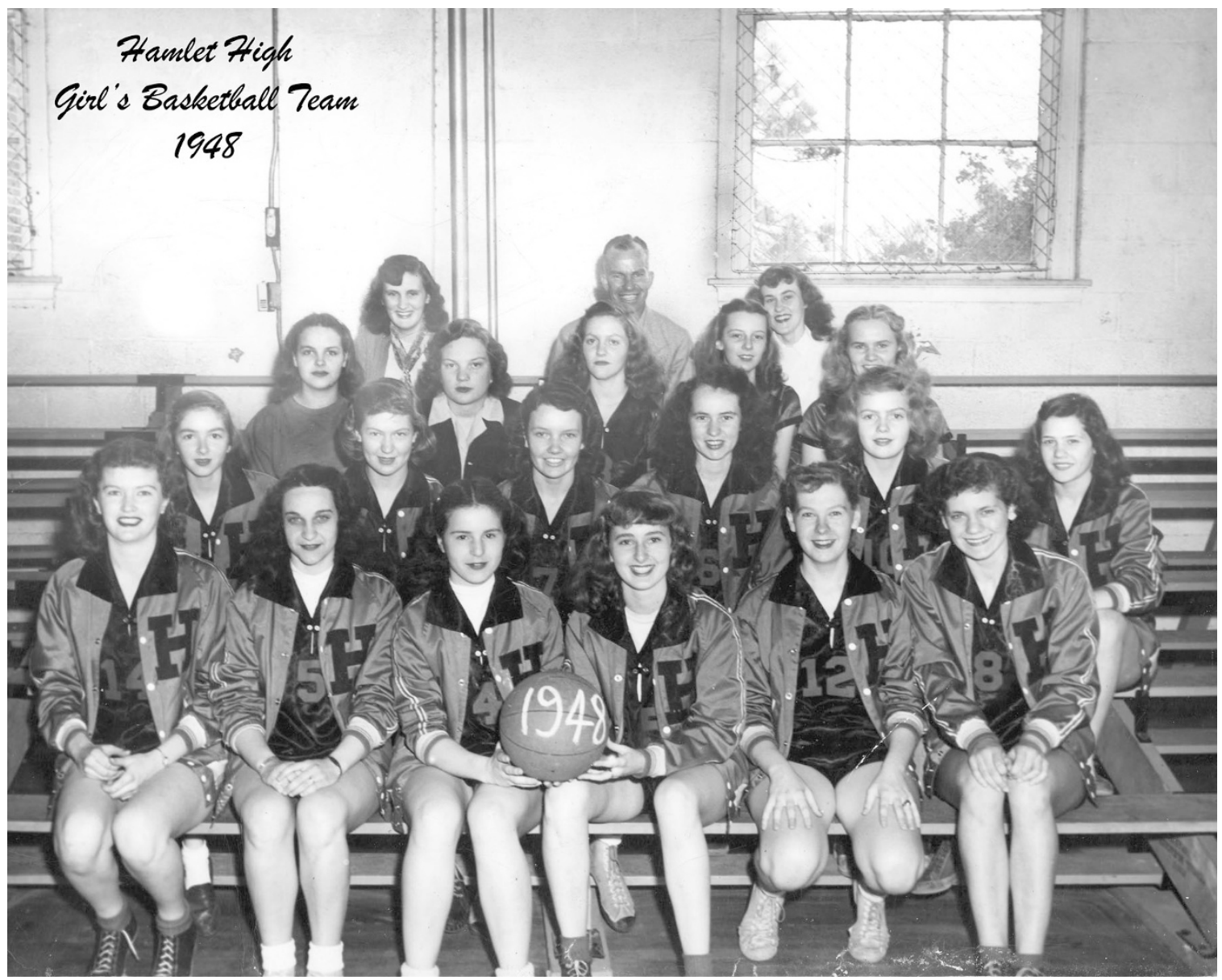

Figure 5. Rebecca's Hamlet High School basketball team. Copyright by C. Edward Buckley, MD. Reprinted with permission.

The third word is loyalty, aka Duke. Becky matriculated as an undergraduate at Duke in 1950, before many of us in this room were born. Aside from a brief sojourn across town for medical school at an unnamed school that sports a lighter color of blue (a 4-year period that she rarely acknowledges), she has been at Duke ever since, now approaching 60 years. As we heard this morning, during this period, she has developed a passion for Duke basketball and rarely misses a game. Among the most amusing stories I heard early on was the time she was away at a meeting giving a series of talks and elected to fly back to Durham in the middle of the meeting to attend the Duke game and then returned to the meeting immediately after the game. The mild-mannered and always proper Becky is an avid fan, and rumor has it that Mike Krzyzewski runs all of his game plans by her before sharing them with the team.

The fourth and final word is leader. Over the course of her career, Becky has had a number of institutional and national leadership roles. She served as Chief of the Division of Allergy and Immunology at Duke for 30 years, as President of the American Academy of Allergy, Asthma, and Immunology, as President of the APS, among many other roles. But most telling in my mind was the stretch shortly after Wesley Burks left Duke to assume responsibilities as Chair of Pediatrics at UNC. As we searched for a new chief of Allergy and Immunology, there was a lot of uncertainty about the division among current faculty, current fellows, and fellowship applicants.

In addition, we were short-staffed from a clinical perspective, especially considering the breadth and depth of the clinical program. At the time, Becky was preparing to decrease her clinical activity. Instead, given the circumstances, she assumed additional weeks of clinical service time. In addition, she increased her level of interaction with the fellows and played a key role in meeting with fellowship applicants and faculty candidates. In brief, she demonstrated the leadership that has characterized her career and has led to her endearment among the countless fellows and faculty who have spent time in the Division of Allergy and Immunology over the years.

Let me close by saying that Becky Buckley is a role model for all of us, as a clinician, as a teacher, as an investigator, and as an advocate for children. She has set a high bar, advancing medicine in ways that have improved the health of children around the world." 


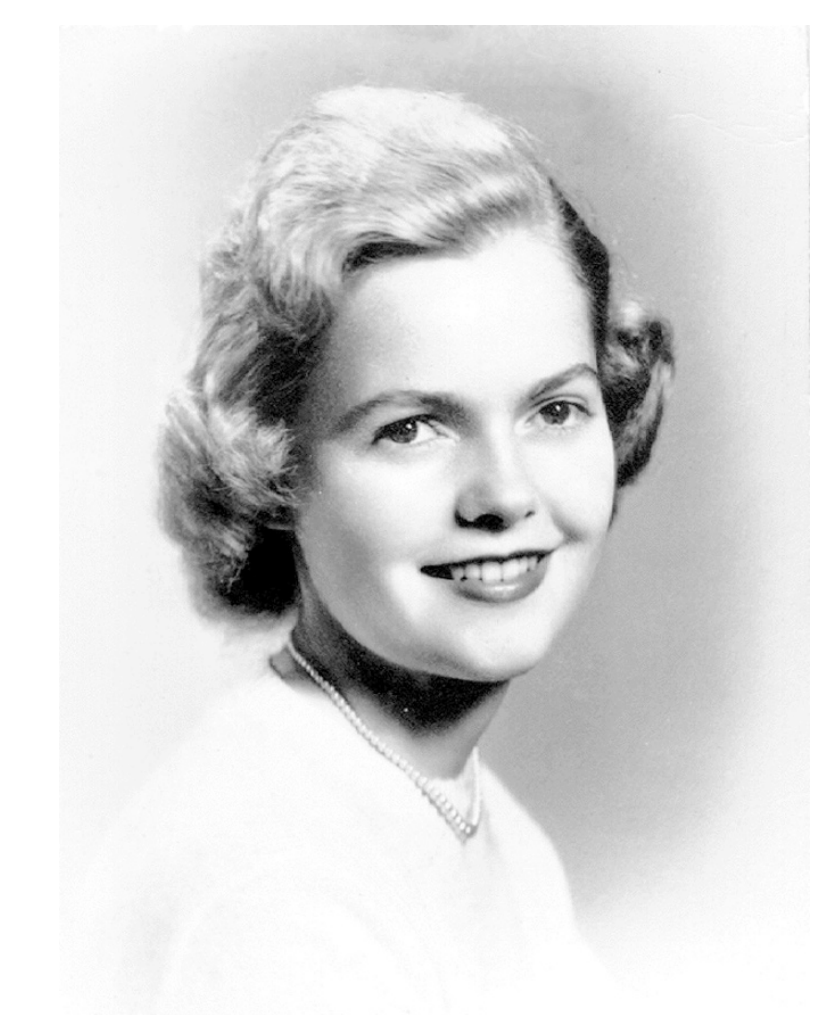

Figure 6. Rebecca's graduation picture from Duke University. Copyright by C. Edward Buckley, MD. Reprinted with permission.

From the late Richard Schiff, Medical Director of Baxter Pharmaceuticals and a former student and Duke colleague:

"It is my pleasure to say a few words about Dr Buckley and our long association since we first met when I was a medical student at Duke. I am here with my wife, Sherrie, who ran Dr Buckley's laboratory for 15 years. These dinner tributes often seem to become either eulogies or roasts, but she certainly isn't ready for a eulogy and I don't think she would appreciate a roast, though Dick Stiehm did roast her warmly earlier today.

I first met her in my second year of medical school, while looking for a sponsor for my $\mathrm{PhD}$ thesis. They recommended that I speak to a new faculty member, Rebecca Buckley, in the Department of Pediatrics. I found her in the Bell Building, an older brick building a few hundred yards from what was then the main hospital. Built in the late 1940s it was unassuming and had all the charm of a VA hospital, with dark hallways and institutional greenpainted walls. I located her in a small office and laboratory. I had never heard of her before that day, but she greeted me warmly, and after a brief discussion she agreed that I could work on a T-cell project that I started in high school, and thus she became my $\mathrm{PhD}$ adviser.

The Bell Building was well known for the work of Joseph Beard, who studied the Rous sarcoma virus in chickens. The building was next to the railroad tracks and there was a large chicken coop by the tracks where Dr Beard kept his chickens. However, Dr Buckley felt right at home, having been raised in Hamlet, North Carolina, which at that time was best known for the chicken plant. The chickens are gone; now the town is best known for its most successful alumna.

She attended Duke undergrad and then UNC medical school, where she learned medicine but not to love the UNC basketball team. For her, there was, and is, only one basketball team. Anyone rooting for another team, especially the one down the road, quickly learned to keep a low profile. In spite of the fact that she seemed to work 24 hours a day she never missed a Duke basketball game, even the away games during the ACC tournament. In the years when the Academy had the audacity to have the annual meeting during the ACC tournament she would disappear and fly back for the Duke games and then reappear to give her presentations.

I never did work on my proposed project because a few months after I started working in her lab, a resident took a family history on a child with recurrent infections and discovered that the family had lost 8 of their 17 children to infections. He consulted Dr Buckley and that led to the diagnosis of the first child with severe combined immune deficiency at Duke. We transplanted that child, but the graft eventually failed, and over the next 10 years or so every attempt to transplant a SCID who didn't have a match failed.

In 1980 she perfected a method to remove $\mathrm{T}$ cells from bone marrow and that started what is still the largest series of successful mismatched transplants for severe combined immune deficiency in the world, which she told you about earlier at this meeting. You heard about the importance of early diagnosis and newborn screening, but what wasn't emphasized was that it took years before anyone listened.

For years she travelled around the world preaching the importance of newborn screening with the passion of a Southern Baptist minister. Finally, within the past few years, newborn screening has become a reality in the US and other countries will soon follow suit. This might never have happened if not for her persistence, passion, and dedication to these children.

Dr Buckley is a great teacher and always made sure we were well prepared for presentations at meetings. She would bring a slide projector to meetings and instead of sitting around the bar she would have us rehearse our presentation until we nearly had it memorized. As a secondyear graduate student, I was giving my first presentation at a national meeting. It was in the plenary session at the Academy of Allergy and Immunology, held in the grand ballroom at the Washington Hilton. There were thousands in the audience. I was sitting in the front row, nervously waiting to present.

Dr Buckley walked in and sat down next to me and said that she had a better conclusion and proceeded to give me a yellow pad with writing in the dreaded red ink that she 


\section{Introductory address: Howland Award $\quad$ Special Article}



Figure 7. Dr Buckley with her husband, Edward Buckley, MD, and her family. Copyright by C. Edward Buckley, MD. Reprinted with permission.

used to bleed on all our manuscripts. There on the piece of paper was a paragraph, partly crossed out, with an arrow to another paragraph, and with additional arrows pointing to other sentences. It was a good thing I was young and had a strong heart. But I gave the presentation, using the new conclusion. I survived. And learned that day that it is never too late to make something better.

Dr Buckley has received many awards, none more important than the Howland award. I did my pediatric training on the Howland ward at Duke, so I feel a sense of the history that underlies this award. But I think that her greatest achievement and that which makes her most proud is the knowledge and passion for the care of patients that she has imparted to the many students and fellows whose lives she has touched."

Dr Wesley Burks, Chair of Pediatrics at the University of North Carolina, a former trainee and Duke colleague:

"I want to thank you for the opportunity to take part on this occasion to honor $\mathrm{Dr} \mathrm{B}$. Yes, that is correct, that is what many, many of her trainees and I call her. It was good to hear Richard and Joe talk about Dr B. and their experiences with her. I had the unique opportunity of being trained by $\mathrm{Dr} B$. and then returning to Duke after almost 20 years and working with her on the faculty.
In thinking how to honor Dr B. today, I thought about all the things we could discuss but three objects came to mind consistently: a paper, a pen, and a string of pearls. So what do those three items have to do with Dr B.? Please let me spend a few minutes to tell you why.

First, the paper. The first time I heard of Dr B. I was a pediatric resident and we had a patient with hyper-IgE syndrome or Job syndrome or Buckley syndrome or whatever you want to call it. I still remember the paper and the picture of one of her patients before and after antibiotic treatment. When a syndrome is named for a particular individual, then that person obviously has made some significant contributions to that field of research. At that time I didn't realize how much of a contribution Dr B. made but I knew her research had to be extremely important. Through the guidance and intervention of one of her trainees, Dr Marty Fiser, I went to Duke for my training under Dr B.

In retrospect, that paper now signifies for me the major contributions she had made to the care of patients with immunodeficiency diseases. In her lifetime, the care of these patients has changed dramatically. Not only do we understand the clinical disease complex, we now know for many of these diseases the genetic and molecular mechanism of why a patient has an immunodeficiency disease.

So now we have the paper. Next, the pen, specifically a red pen-Dr B.s trainees, at least prior to everything being 
online, will know what I mean. The simple red pen signifies her training of me and many, many other allergy and immunology fellows.

In writing a manuscript with her we all were warnedappropriately so-that it would return with more red than original black type. I have vivid memories of the first manuscript I did with Dr B. and Dr Sampson; unexpectedly for me, the study wound up in the New England Journal of Medicine. The manuscript comes back and you couldn't tell there was any original typing at all, it was solid red and I mean solid red! Dr B. took the time to "suggest" changes in the manuscript to make it better and I think it turned out okay.

There have been well over eighty allergy and immunology fellows to come through Duke in the last 5 decadesyes, I said decades. We know that Dr B. helped train almost all of them, so I truly can't imagine how many red pens she must have gone through! They signify her incredible investment in the individual trainee as well as the future of the field as a whole.

Let me tell you a bit about how that training went. There was the first year of fellowship, where you were given the keys to Rankin (the immunodeficiency research ward), the keys to 5100 (where the rest of the patients were), the keys to where the mitogen counter was (for the immunologic assays that were being done on the whole world), and the keys to the roof of Duke Hospital (where the pollen counter was). You just got the directions about where to go and what to do.

In case you were wondering, I know how Dr B. taught her kids to swim: she threw them into the pool and they figured it out pretty quickly! That is how that first year of training went, an immersion experience for sure.

Dr B. came into my life at an important development time for sure. There are many, many things I do unknowingly that emulate Dr B. in how I help train others. I understand better now the importance of seeking mentors out, continually and without fail throughout our lives. It's highly unlikely that a mentor will fall out of the sky into our lap. It is equally important to seek different mentors to guide each one of us through the different parts of our lives.

Two major aspects of successful mentorship are compassion and perseverance. Each has a role in our development as a person, as a physician, and as a future leader. If I emulate Dr B. in any way as a role model, it would be in her compassion for her trainees and her perseverance in our training.

Going back to the other key component of mentorship: perseverance. I dare say it would have been much easier as I think about it now to just write a blank manuscript, but no, Dr B. let us write and write and write and write and...well, you get the picture. Despite our constant foibles in training, she always worked patiently with us, helping us to become subspecialists and researchers. Sometime we wondered why she did things the way she did, but it worked, and I don't exaggerate at all when I say that we are better for it.

Lastly, when I think of Dr B., I think about her pearl necklace. Another teacher and mentor of mine, Mike Frank, has said for years "the way to find Becky at a game is to find the pearls and you'll find her!"

To me, the pearls signify the type of person she is: the consummate southern woman of distinction, class, and elegance, who works harder than most people I know and still manages to prioritize her family and friends. And, of course, she loves Duke basketball!

Dr B., as you know now, is from Hamlet, NC, where others-including John Coltrane, a famous jazz saxophonist, and Tom Wicker, a famous New York Times columnist-are from: quite impressive company. The values she acquired growing up in that southern rural town she has passed on to many of us. Interestingly, previous Howland Award winners, including Floyd Denny, Russell Chesney, and Dr B., all have ancestral roots in small towns near the eastern borders of North Carolina and South Carolina.

Please think with me now back to the 1950s, and the role that women played in society and in medicine particularly. Dr B. grew up in that era and did pretty well, don't you think? I had the opportunity in Arkansas and at Duke to hear her talk to other women faculty about the way she approached work from a woman's standpoint. The conversation with her was always, "I just did what was needed and the right thing to do." Sure makes it sound easy, doesn't it? Surely at times she felt a different amount of scrutiny and encountered different obstacles than her male counterparts, but she figured out a way to "just do it," and do it quite well! She was the original Nike woman-she just did it!

In closing, I want to tell you a story from the 1991 movie City Slickers-yes, the one starring Billy Crystal. I did get something amazing out of that film called "Curly's Law." The late Jack Palance played the tough old cowboy character Curly in the movie. Here's the scene where Curly espouses his life philosophy to Mitch (Billy Crystal's character):

Curly: Do you know what the secret of life is?

Curly: This. [Holds up one finger]

Mitch: Your finger?

Curly: One thing. Just one thing. You stick to that and the rest don't mean [expletive].

Mitch: But what is the "one thing"?

Curly: [smiles] That's what you have to find out.

I do not know what your "one thing" is, but I can tell you what Dr B's are: the paper, the red pen, and the string of pearls. They represent this one incredibly accomplished individual who has impacted lives all over the world." 